\title{
RELIGION AND MALAY-DAYAK IDENTITY RIVALRY IN WEST KALIMANTAN
}

\author{
Yusriadi ${ }^{1}$, Ismail Ruslan ${ }^{1}$, Nunik Hasriyanti ${ }^{1}$, Mustolehudin ${ }^{2}$, \\ and Chong Shin ${ }^{3}$ \\ ${ }^{1}$ IAIN Pontianak, Indonesia \\ ${ }^{2}$ Religious Research and Development Center, Semarang, Indonesia \\ ${ }^{3}$ Universiti Kebangsaan Malaysia, Selangor, Malaysia \\ Email: yusriadi.ebong@gmail.com
}

Received: January 20, 2021

Accepted: April 16, 2021

\section{Abstract}

Ethnic rivalry triggers competition among individuals, certain actors, and groups. Often, the competition is due to political factors while religion becomes a structural legitimacy. This paper examined how the rivalry between Malay and Dayak in West Kalimantan affected certain groups' identity. The data of this paper were obtained through a documentation study by reviewing publications and writings on the issue of rivalry and interviews with some figures in West Kalimantan. The result concluded that the rivalry between Malay and Dayak in West Kalimantan was tight due to political factors. The two equally dominant communities have long competed since the colonial period in West Kalimantan. Today's rivalry has taken place since Indonesia's reformation in 1998 and let both groups maintain their identity, and, in some cases, lead to unclear boundaries. They do not live as neighbors but brothers. However, religion remain an essential factor amid the situation and cause the rivalry stronger.

Persaingan etnis memicu persaingan antar individu, aktor tertentu, dan melibatkan kelompok. Seringkali persaingan disebabkan oleh faktor politik, sedangkan agama menjadi legitimasi struktural. Makalah ini berupaya untuk 
melihat bagaimana persaingan antara Melayu dan Dayak di Kalimantan Barat berimplikasi pada identitas kelompok. Data untuk makalah ini diperoleh melalui studi dokumentasi dengan melihat publikasi dan tulisan tentang isu persaingan, serta wawancara dengan sejumlah tokoh di Kalimantan Barat. Kesimpulannya, persaingan antara Melayu dan Dayak di Kalimantan Barat sangat kuat karena faktor politik. Kedua komunitas yang sama-sama dominan ini telah bersaing sejak jaman penjajahan di Kalimantan Barat. Persaingan saat ini telah terjadi sejak reformasi Indonesia pada tahun 1998. Melalui kompetisi ini, masing-masing etnis Melayu dan Dayak mempertahankan identitasnya, dan dalam beberapa kasus menciptakan batasan yang kabur. Mereka ditempatkan sebagai tetangga, tetapi sebagai saudara. Namun, agama tetap menjadi faktor penting di tengah situasi ini, dan membuat persaingan keduanya semakin kuat.

Keywords: religion; ethnic rivalry; identity; Dayak; Malay.

\section{Introduction}

The reformation in the late 1990s has changed the face and structure of ethnic relations in Indonesia (Jones, 2013; Alfarabi et al., 2019). When various problems were initially centered, they were handed over to the regions. It became the business of local community. The competition caused a stronger rivalry, and each ethnic group strengthened solidity and solidarity with various considerable efforts.

West Kalimantan was one of the areas directly affected by Indonesia's 1998 reforms. Big eruptions accompanied these changes. In 1997 there was a conflict between Dayak-Madura, and then in 1999 there was a conflict between Malay-Madura (Amirrachman, 2019; Klinken, 2007). Although what surfaced was Dayak-Madura and later Malay-Madura, Madura was targeted by two large groups in West Kalimantan, after the reformation, the subsequent rivalry showed Malay-Dayak (Djajadi, 2004). As two large groups with balanced strength, on the scale of West Kalimantan, it was uncertain who was stronger, or who was lost. Compared to Madura, the situation was different as a small group, Malay and Dayak quickly came up as the winners in the "war".

Malay-Dayaks rivalry has long been standing up to now. Although the scale is not as intense as what happened in 1997 and 1999, it is difficult to compare with the current situation. However, their relationship is certainly dynamic. Iqbal Djajadi (2004) calls it tidal; sometimes intimate and sometimes unstable. The battle is also expanded into the terrain, not only in politics but 
also religious, social, economic, and cultural aspects. (Yusriadi, 2018; Yusriadi; $\&$ Muttaqin, 2018).

Haitami Salim, a scientist who was also the Secretary of the Majelis Adat dan Budaya Melayu/Malay Customary and Cultural Council (MABM) of West Kalimantan, wrote:

"Especially in cases of violence in West Kalimantan, the author does not dare to declare a religious conflict because the group involved is an ethnic community who incidentally differed beliefs by using religious symbols and involving religious adherents" (Salim, 2012).

Traditions clash in Kalimantan. There has been an adaptation between local traditions and those brought by nonnatives. One of the examples is the acculturation of the tradition Baayun Anak to Maulid Baayun in South Kalimantan. Before converting to Islam, Dayak Kaharingan people who lived in Banua Halat Village usually held an Aruh Ganal ceremony followed by Baayun Anak (Jamalie, 2014). It is certainly different from the local culture in West Kalimantan. Yusriadi's study of Kebahan tradition shows that speakers of Kebahan have terms and narratives about living in harmony. The concept of pirate resistance, ngawa, criticism of Kerampak Kebahan, etc. An example of how they reminded themselves of their role and position as a counterweight in pluralistic society (Yusriadi; Ruslan \& Hariansyah, 2018).

Cultural intersections can create conflicts, such as what happened to Madurese, Dayaks and Malays. There were some violence and ethnic clashes (Haba, 2012). One of the ethnic tragedies in Indonesia was the bloody conflict of Sangau Ledo and Sambas, which forced Madurese to leave West Kalimantan Province, where they had lived for many years. After the uncertain social and ethnic relations among Madurese, Dayaks and Malays due to the conflict, the situation gradually improved. Social interaction at the conflict site was much better than that during the dispute. Social institutions in ideology, religion, economy, politics, language, education, culture, and other social norms theoretically led to social friction and ethnic stereotypical views prone to raise the seeds of conflict in social reality. Selfishness and fanaticism respect ethnicity (Al Humaidy, 2007).

Melayu and Dayak ethnics uphold the values of local wisdom, such as togetherness, obedience, and religiousness. The historical inheritance (custom house) of Melayu and Dayak ethnics reflects local wisdoms, which are community unifying element and essential meaning of what is good and bad in life. It also contains inter-community interactional organization, community solidarity development organization, social organization, cultural art center and 
inspiration to the formation of specific personality as well as the realization of higher community cultural values in West Kalimantan (Batubara, 2017). Besides, study also found that Dayak women played a role in maintaining their culture (Suminto \& Ermawati, 2018).

This article discusses the situation of rivalry between Malay and Dayak in West Kalimantan and the influence on identity construction of each group. The basic assumption is that the rivalry influences each other's efforts to maintain identity, and the maintained identity related to culture improves their relations. In contrast, identity related to religion brings their relations stronger.

This study is prominent to provide an academic solution in suppressing cultural conflicts between tribes, especially the Dayak ethnic groups of West Kalimantan and the Malays. The solution to this identity competition can be sought, one of which is cultural diplomacy between the disputing ethnics. A study shows that cultural diplomacy can be interpreted as exchanging information, ideas, arts, and other cultural aspects to create mutual understanding in establishing interactions with other groups (Sutantri, 2018).

Another article that strengthens this study is written by Joko Tri Haryanto. The dynamics of religious and cultural relations in Java and Kalimantan ethnicities can be the glue of harmony. A research conducted in Central Java, East Java, and Central Kalimantan at least suggests that the dynamics of Muslims' internal relations in the three regions show three patterns of relations: the relationship between religion and local traditions, religious and ethnic relations, and religious relations and thought. Among the three relations, the strongest social cohesion in Muslims' internal relations is the that between religion and local tradition (Haryanto, 2015). Meanwhile, the other two forms of relations still leave dissociative interactions in the internal relations of Muslims. Religious and cultural relations can be a strategy to build internal religious harmony in general.

Another study on social exchange is the folklore of Dayuhan Intingan as a suggestion of harmony. The results denote that the folktales of Dayuhan and Intingan are the source of the norms of harmony between Banjar and Meratus Dayak Tribe. Dayuhan and Intingan are two brothers, brothers who, despite their different beliefs, still maintain brotherhood. The values of harmony in Dayuhan and Intingan stories are humanitarian unity, mutual trust, fulfillment of tolerance, cooperation, mutual respect, and conflict resolution. This story inspires Banjar and Dayak tribes that they are brothers; therefore, harmony 
must be maintained (Haryanto, 2018). Studies show that identity competition between Malays and Dayaks in West Kalimantan can be carried out through a cultural approach to reduce a conflict.

\section{Method}

This research employed a qualitative approach. Data ware explored in deeep and comprehensive understanding. Field data ware obtained through the collection of library sources. The materials had been published that they had been read and assessed by public. They are scientifically reliable. An argument needs to be supported with data and scientific studies, so it can be on concern.

In addition to books, materials from other sources such as news, research reports, and blogs, ware also used to construct the information needed. Data or information clarification was carried out with relevant informants. Some people from the Dayakology Institute and the West Kalimantan Malay Cultural Customary Council had been contacted and interviewed. This approach helped researchers better understand the dialectical process and the phenomena behind the rivalry.

Malay and Dayak in West Kalimantan were chosen as the object of this study because both communities were dominant in the province. Both are indigenous people, each of which are amounted to $38-40 \%$, so their gaps in number ware small. The data were then analyzed using a structuralphenomenological qualitative approach. The phenomena, actors, their meanings and implications are interpreted and summarized in a framework of arguments. Following the purpose of this study, it identified the rivalry between Malay and Dayak that affects preservation identity and makes them closer.

\section{Ethnic Rivalry and Identity}

Ethnic rivalry is a battle or competition between ethnic groups in a multi-ethnic society. When Deutsch introduced the concept in 1949, rivalry was perceived negative because there lies a desire to win the competition and brings down others. However, it has also been gradually used for a positive meaning. In competition, every ethnic group wants to look dominant, or not to be defeated and controlled. Therefore, solidity among group members is built and maintained. Ethnocentrism arises unexpectedly, looking for formulations by pragmatic interests. There are efforts to "compete" to be the best in the midst of rivalry. 
Rivalry occurs in the middle of a majority situation or when the power is balanced. The examples of this situation can be traced in several places, such as the dispute in Malaysia between Chinese and Malay (Embong, 1999; Crouch, 2001) and in Ambon between indigenous Muslims and Christians (Collins, 2001:385). Meanwhile, when the power is not balanced, one ethnic group usually absorbs another ethnic group, build alliances or collaboration. It happens to ethnic minority groups, i.e. Arab/Muslim descendants and residents in East Kalimantan and West Nusa Tenggara (Magenda, 2014), Chinese and Javanese in Central Java (Markhamah, 2000), and Malay in Singapore (Riyanto et al., 2018).

In rivalry situations, and usually more related to politics, ethnic identity is formed and confirmed to show strict boundaries between one group and another. Sometimes the forms of identity are not always the same, changing according to circumstances. Eventually, identity can come up from various elements, including culture, language, and religion (Embong, 1999; Yusriadi, 2014). These elements are chosen and used for pragmatic purposes to determine whether an identity will be equated or differentiated. It is not essential how far the distance or the difference between one identity and another; even in many instances minor differences can be the decisive differentiators (Labov, 1978; Collins, 2001; Yusriadi, 2014).

\section{Malay Dayak in West Kalimantan}

Malay and Dayak are the names of two largest ethnic groups in West Kalimantan. Malay refer to the residents, Muslims, who speak Malay and claim to be Malay. While Dayak refer to the non-Muslim residents, speak their mother tongue instead of Malay, and claim to be a Dayak. However, from this identification, they can be easily identified from their religion. So, Islam is used to see whether a person is a Malay or Dayak (Yusriadi, 2008). The number of Malays and Dayaks in West Kalimantan is relatively balanced. Although there is no official data on their number, Malay estimates in West Kalimantan reach 30 percent, while Dayak is estimated at 40 percent (Yusriadi, 2008). This amount is supported by pockets of settlement of each region that forms ethnic geopolitics, such as Pontianak, Mempawah, Sambas, Kubu Raya, Kayong Utara. Whilst, Hedgehog, Bengkayang, Sanggau, Sekadau, are Dayak pockets. The number of the two communities is balanced in Kapuas Hulu, Sintang, Melawi, Ketapang. Because of this situation, the rivalry between the 
two groups is always intense. They fight for political and economic fronts, while culture is made as a tool for this purpose.

In the interest of rivalry, these two groups are trying to strengthen ethnic solidity. The potential is mobilized, especially concerning politics and economics. These two issues are always related to the history of the region. In West Kalimantan, in the early days, Malays were the dominant group. The Malay kingdom has several trading points, and controls the regional economic activities (Ishar, 2015). Tax or belasting is an important source in this political-economic situation (Veth, 1854). The power of these Malay kings, which is conveyed today, is often mentioned in Malay-Dayak relations in West Kalimantan. For example, when talking about the regional regulation plan on the protection and recognition of indigenous and tribal peoples, the definition of indigenous territories is linked to the Malay kings' territory, not only Dayak.

The differences in ethnicity, religion, and culture among Malays and Dayak tribes in West Kalimantan that are potential for conflicts can be mitigated by local cultural exchanges or cultural marriages of each of the conflicting ethnicities. Haryanto's study can be a reference for how various ethnic groups can live in harmony through the media of Dayuhan and Intingan folklore in South Kalimantan (Haryanto, 2018). The two main forces balance the ethnic of Malay and Dayak in West Kalimantan. They become a social capital for the two groups to build harmony.

\section{The Preservation of Malay Identity}

Malays affirm their identity in some ways and agendas. Important actors in this matter are the elite, which consist of intellectual circles. Campus figures together with political figures confirm certain symbols to give the Malay a character. The Malay organization's birth, the Customary and Cultural Council (MABM) of West Kalimantan in 1997 must be regarded as an important factor behind the preservation of Malay identity today (Kristianus, 2016). The structure involves Ismet M. Noor, a police from PAN, Khasmir Bafiroes and Awang Syofyan Ghazali from Golkar, Imien Thaha from Golkar. While from campus, they are Chairil Effendy, who later becomes the Chancellor of Pontianak Untan, and Hadari Majeri. The religious element, the cleric for example, is not involved in this process.

Now the situation is more or less the same, MABM shows a combination of campus intellectuals/politicians and politicians, and also bureaucracy. Critical 
management in MABM especially in the regions now has more politicians, some of whom serve as regional heads. MABM is formed at the provincial level, and then it branches in the district area. Although the focus is on culture, politics cannot be ignored. This organization organizes various activities, especially cultural activities that are routinely held. Academic activities also received attention, such as seminat and book publishing. MABM carried out the seminar and several times socialization activities. Besides, semi-religious activities are also held such as halal bihalal after Idulfitri and breaking the fast together.

In these activities, the symbol of Malay is displayed. Malay cultural forms are promoted. The Malay permanent event is West Kalimantan Malay cultural festival, with 14 stemas (branches) of the race, including: Malay singing competition, silat art, Malay bridal make-up, Malay motif design, Malay dress for children, traditional Jepin dance, traditional ceremony of plain flour, Malay poetry, unrequited rhymes, laps and uring tops, hadrah art, speech contest, and bidar sampan competition.

Besides, similar activities are also held by Regional MABM. The scale of this activity depends on the ability of each region. It depends on the local government's attention to the local MABM. Malays have assemblies of Malay kings who symbolically have a significant role in society. There are 13 Malay kings in West Kalimantan: Pontianak, Mempawah, Sambas, Ngabang, Sanggau, Sekadau, Sintang, Matan, Tayan, Kubu, Ketapang, Silat, Bunut (Ishar, 2015; Ruslan, et al., 2019). This royal institution has been built since the $17^{\text {th }}$ century before the Netherlands' arrival (Ishar, 2015; Purba, 2014). After the Dutch and Japanese arrival, some kingdoms were lost because their roles were politically and economically insignificant. After the reforms, these institutions were revived, especially when ethnic politics were at the forefront of issues and movements.

Under the Malay kingdom's informal authority, cultural activities in a tourism format were organized, for example, Pontianak with haul and ziarah kubur activity (grave pilgrimage), Mempawah with robo '-robo' (praying for a sea on Wednesday), Tayan with mandi bedil (washing heirlooms), Ngabang with tumpang negeri (event for safety), and Sanggau with paradje' (rejecting danger). In addition, certain regions have a tourism plan that seems to be cross ethnic. For example, Pontianak holds activities to commemorate city birthdays, commemoration of culmination points, and Malay bridal contests; Ketapang 
has a roll poetry contest; Sambas has activities between Ajong and Salo spills, Singkawang has saprahan activities; and Kubu has haul activity, Kubu.

Through these activities, Malay identity is displayed. One of Malay features displayed is Malay clothing, which is used by everyone involved. The result, in recent decades a unique form of fashion has been seen. Today's Malay clothes are related to Muslim clothes, and Koko clothes, as well as Songket and batik "Malay". Women wear headgear or veil while men wear headgear, in the form of skullcap. Tanjak Melayu now also has a place.

Regional specialties are served and even some are contested. Spicy and sour Pacri pineapple is considered a typical Malay food. Likewise, with Temet, Regional arts such as poetry, Hadrah, Jepin, dance, song are displayed on stage. The performance was accompanied by Malay rhythms and parts of the Middle East. Society refers to Malays and cross ethnicity, competing and participating, displaying, modifying, creating creations related to their fields, and becoming "part of Malay". The public or the general public has been constructed with thoughts about the form considered as West Kalimantan Malay.

Malay identity can also be seen from the names commonly used. Malay people have names related to Arabic; for example Abdullah, Muhammad, Nur, Siti, etc. The use of English, Javanese, or names popularized by artists also begins to be found in Malays. This option is seen more attractive. Meanwhile, Malay language cannot be a Malay identity today although they use it as the primary language because it is used in cross-ethnic interactions. It is also popular among non-Malay people (Yusriadi, 2018).

\section{The Preservation of Dayak Identity}

What happens to Dayaks in West Kalimantan today is the result of a community empowerment movement initiated by many actors in Pancur Kasih Social Work Foundation. The movment is organized in an institution called Pancur Kasih Empowerment Movement (GPPK). The name Pancur Kasih, and later facilitated the establishment of the Junior High School, St. Francis Asisi in Pontianak, reflected the Christian paradigm in the early movement (Giring, 2013). The social philosophy of the church is the breath of this movement. GPPK activists consider that Dayak identity needs to be strengthened, more precisely to re-establish that identity (Efraim, 2013). In 1940-1950, Dayak reached a political peak when Ovang Oeray, a student of the Catholic seminary in Nyarumkop, Chairman of the Dayak Party of 
Communion, became a constituent member, and served as governor of West Kalimantan in 1960-1966 (Aju \& Usman, 2012).

The GPPK activists are young people, including AR. Mecer, teachers at the Brothers School, Thomas Lay, Saikun Riady, Kadus Firmus, Maran Marcellinus, Pastor Heliodorus, Aloysius Milon Somak (Widjaya, 2013: 70). Also, they establish the Dayakology Institute (ID) driven by activists, such as Stefanus Djuweng, Jhon Bamba, and several other names written in the researches and publications, such as Plorus, Herman Ivo, Seselia, Albertus, Sujarni Alloy, Yovinus, etc.

On the other hand, Dewan Adat Dayak/ Dayak's Customary Council (DAD) was formed as a forum for cultural and customary movements, in 1985. In the beginning, DAD was formed in Pontianak District, in one of the crucial areas of Dayak Kanayatn. Later, DAD districts and provinces were formed, and in the sub-districts. The institution met with the knot of the indigenous community, formed by traditional leaders in the villages or local traditional areas. These activists explore politics and bureaucracy. Supriyadi (2009) records in detail several regents held by Dayaks; for example Porcupine, Bengkayang, Melawi, Sintang, Sekadau, Sanggau.

Synergy is built with politicians because this movement promotes the community empowerment movement in education, economy, social, culture, and politics. Besides, the political situation does open up space for the rise of local power - and this applies throughout Indonesia, regents, deputy regents. Even at its peak, the position of governor of West Kalimantan can be controlled. The presence of Dayaks at the top of provincial and district leaders opens more expansive space to develop and maintain Dayak culture. Cultural activities are organized, and cultural houses are established. In all cities, there are traditional Dayak houses. At the provincial level, there is Rumah Radakng which is adjacent to the West Kalimantan Malay House.

Activities that have become fixed calendars are Dayak Gawai, Naik Dango, Notokng, etc. This activities are now held live in all regions. Many art galleries support them. The activities, as well as Malay cultural festivals, display a variety of arts, such as songs, dances, carvings, Dayak clothing, characterized by beads and ordinary clothes with the elements of bark and carvings of plants or animals; Dayak cuisine, such as food from growing ingredients; certain plants and animals, Dayak literature with arts in the form of Sengayong, Bekana, Bekondan, Bujang-Dara Dayak, as well as display of agricultural tools; 
hammer, mortar, penangkin; and types of Dayak games; such as chopsticks, mandau, shields.

Community participation in this activity is extraordinary. It is always crowded. Therefore, not only the committee facilitated the activity, participants are also actively involved. They prepare themselves to come to the event since a few weeks and even months before. The visitors are also enthusiastic. They give supports while also learning from what is displayed. What they see is inherent in memory, and it generates concepts about Dayak. Religious institutions also provide space for the maintenance of Dayak culture. In addition, Christmas activities with Dayaks are routinely carried out. The police are united to support this event. Banners and publications are installed to revitalize the organization. At this event Dayak cuisines and Dayak clothings are displayed. Dayak dances and songs are also performed.

Dayak Islam is present in that situation. Formally, this group is converted to Islam in 1999. The founding figures of this organization were academics from Tanjungpura University, the Bureaucracy and Politicians. They bridged the gap between Malay and Dayak, by giving a special impression. This movement was influenced by Central, South and East Kalimantan, where many Dayaks who embraced Islam continued to come up as Dayaks. Aside from that, the Association of Kebab Katab also appeared. This group was taken into account and included in the Malay group, and categorized as Islamic Dayak. Katab Kebahan, presenting itself to be no longer Dayak Islam, and also not Malay (Widjaya, 2013; Yusriadi, 2018; Prasojo, 2011).

\section{Preservation in the Rivalry}

Malay and Dayak rivalry is alluded to in the previous section. In addition, the political fields discussed by Djajadi (2004), Kristianus (2016), and Yusriadi (2018), occur within the cultural sphere. Culture has become a front in that rivalry. Malays have a Malay house, Malay culture festival, and various cultural activities. Dayak also have Rumah Radakng, Gawai Dayak, and various cultural activities. In terms of history, Malay history is longer because it is related to the kingdom, while in terms of cultural movements, Dayak is more advanced. In terms of supporting organizations, DAD was established in 1985, while MABM was established in 1997. Dayak activities are also held earlier than the Malay Festival. But even so, the two ethnic groups mutually make the other group as a comparison. Dayak community empowerment movement make

el Harakah Jurnal Budaya Islam Vol. 23 No. 1 Tahun 2021 
a long history of Malay republic and kingdom as a comparison. While the Malays found MABM organization, they make DAD a comparison.

Gawai parade on the city road's main section will be a record for the march during the cultural festival. Malay festival activities will be more meaningful if more festive than the Dayak device, and the Dayak device will be more meaningful if it is more crowded than the Malay festival. In such situations, rivalry generates positive impacts. Creative ideas of activity and culture develops among the two communities. Clever and intelligent creators from each community come up, mainly through art galleries.

Interestingly, there are efforts to build a connecting bridge between Malays and Dayaks amid the rivalry. Especially after the West Kalimantan conflict between Dayak-Madura in 1997, and Malay-Madura in 1999. The birth of Islamic Dayak in West Kalimantan in 1999 is an example of this effort. So, the position of binaries in frontal politics is bridged with cultural efforts. Culture becomes a connecting bridge.

On the more technical side, cross-ethnic dance creations are now packaged. Cross-ethnic dance is a dance of Malay, Dayak and Chinese. There is also the narration of Tidayu, which means the Chinese, Dayak and Malay fraternity. Differences in musical accompaniment, clothing, and the basis of movement are united. On several occasions, the dancers are not always of certain ethnicities. So, as part of cultural performance, they can dance three types of dance at once.

\section{Discussion}

The preservation of ethnic identity in West Kalimantan, both Malays and Dayaks, moves to follow religious keel. Religion and religious figures of Islam and non-Islam, have become symbols and important parts since ancient times when the Malay kingdom came to power and shaped Malay characteristics through art and cultural traditions. Islam has become an essential role for defining groups. As mentioned above, Islam is a part of Malay's meaning, so Malay and Islam become two sides of a coin.

On the reverse side, Islam is also a part of the meaning of the Dayaks. When Dayak are interpreted as non-Muslim natives, all other than Malay (Islam) will be included in the Dayak category. If Dayaks are seen as adherents of traditional religions - the term was previously not a religion, Gawai was a part of traditional Dayak religion rituals. The program's beliefs reflect old beliefs about the spirit of rice, rice gods or gods and Jubata. Although the 
flow in Protestantism is quite resistant to local culture, it is compromised in this situation.

The same placement also allows Dayaks to hold "Christmas Together Dayak" activities in cross-ethnic and non-Islamic cross-religious situations. This activity has even been considered an inseparable part of annual rituals, in Pontianak, Sanggau, and several other places, to show examples. In terms of language use, choice of names for example, there are two critical situations. There are two "strong" groups in each group. Malays who adhere to devout Islam and devout Christians, choose names that reflect their Islamic identity and Christianity. Arabic and Latin names are apparent, even forming a stigma among society. Muhammad, Abdul, Nur, Siti, the suffix Din, is the name of devouted Malays, while names with "Us-us", like Marius, Martinus, Albertus, are the choices of Christians (Aditya, 2018). Although in other situations, with the choice to give names based on the names of artists or mixers and the father and mother's names, leading the names not to become a collective identity for these two groups.

Malay clothes and brackets, hoods, plain black skullcap and white skullcap, in addition to climbing, are "mandatory" clothing in the Malay community. While in the Dayaks, ordinary clothing is paired with beads and bark, or embroidered with a root pattern and a particular image, is an essential their characteristics today. Tattoos (sometimes written with markers or coloring), long ears, are still considered essential but are no longer considered significant as a distinctive identity (Yusriadi, 2008). Whereas in the past, this characteristic was the identity of Dayaks (Widjono, 1998). It is what is called the pragmatic choice of identity (Yusriadi, 2014).

Looking at what happened to Malays and Dayaks in West Kalimantan, the statement of Galtung (1996) is quite relevant, "conflict flows like an endless river; where it starts and where it ends. Religion becomes part of the conflict, as the conflict of individual actors who transform in their life-cycle, while culture becomes part of structural conflict ". These two dimensions fill the Malay and Dayak intersection spaces in West Kalimantan.

\section{Conclusion}

Rivalry between Malay and Dayak in West Kalimantan has been happening for a long time. The early 1990s, especially after Indonesia's reforms, let local groups rise and strengthened the competition. Rivalry occured (again) and influenced the cultures. Although, in this case, Islam has culturally and 
religiously become a legitimate difference and similarities, Malays and Dayaks have chosen religous identities to widen the differences with other groups, and some have tried to choose identities that eradicates the differences.

Actors from each group give and take the way in that direction. The way has been shown: The God for Malays, because they are Islam, is Allah Subhanahu wa ta'ala, and the God for Dayaks who come from the Garden, is Alatala. The important spells in Malay must begin with the expressions of Allah and Muhammad's formulas, and many Dayak spells also begin with God and Muhammad.

Malay and Dayak names can share the names of artists on TV, or names from a combination of fathers and mothers. The most striking is Rumah Radakng owned by the Dayaks, and the Malay House owned by the Malays in Pontianak, in the same place, next to each other. They live together as neighbors that they can see each other's situation quite well. As a result, this is why the religious and cultural identities in Dayak and Malay relations in West Kalimantan are unique and attractive.

\section{References}

Aditya, F. (2018). Nama pada Orang Melayu Mempawah. FKIP Untan Pontianak.

Aju \& Usman, S. (2012). J.C. Ovaang Oeray: Langkah dan Perjuangannya. Pontianak: Samudera Emas.

Al Humaidy, M. A. (2007). Analisis Stratifikasi Sosial Sebagai Sumber Konflik Antar Etnik di Kalimantan Barat. KARSA: Journal of Social and Islamic Culture, 12(2), 186-195.

Alfarabi, Venus, A., Syafirah, N. A., \& Salam, N. E. (2019). Media Identitas Melayu Pascareformasi di Indonesia. International Journal of Multicultural and Multireligious Understanding, 6(1), 21-31.

Amirrachman, A. (2019). Revitalisasi Kearifan Lokal. Jakarta: ICIP.

Batubara, S. M. (2017). Kearifan Lokal dalam Budaya Daerah Kalimantan Barat (Etnis Melayu dan Dayak). Jurnal Penelitian IPTEKS, 2(1), 91-104.

Collins, J. T. (2001). Contesting straits-Malayness: The fact of Borneo. Journal of Southeast Asian Studies, 32(3), 385-395. https://doi.org/10.1017/ s0022463401000212 
Crouch, H. (2001). Managing Ethnic Tensions through Affirmative Action: The Malaysian Experience. In Colletta, N, Lim, TG, \& Kelles-Vittanen, Social Cohension and Conflict Prevention in Asia. Washinton DC: The World Bank.

Djajadi, I. (2004). The Dynamic of Violence: A Study of Relationship among Ethnic Violence, Ethnic Conflict and Criminality in West Kalimantan. In Presentation Material in Leiden. Kalimantan.

Efraim, B. (2013). Transformasi Ke-Dayakan: Kerja-kerja Institut Dayakologi dalam Pewarisan, Revitalisasi Budaya, Pemberdayaan dan Advokasi. In Francis X Wahono, Gerakan Pemberdayaan Pancur Kasih. Pontianak: Institut Dayakologi.

Embong, A. R. (1999). ldentity and ldentity Formation. Akademika, 55(July), 3-15.

Galtung, J. (1996). Studi Perdamaian. Surabaya: Pustaka Eureka.

Giring, R. (2013). Gerakan Pemberdayaan Pancur Kasih (GPPK). In Francis X Wahono, Gerakan Pemberdayaan Pancur Kasih. Pontianak: Institut Dayakologi.

Haba, J. (2012). Etnisitas, Hubungan Sosial dan Konflik di Kalimantan Barat. Masyarakat $\mathcal{E}$ Budaya, 14(1), 31-52.

Haboddin, M. (2012). Menguatnya Politik Identitas di Ranah Lokal. Journal of Government and Politics, 3(1), 109-126. https://doi.org/10.18196/ jgp.2012.0007

Haryanto, J. T. (2015). Relasi Agama dan Budaya dalam Hubungan Intern Umat Islam. Jurnal SMART (Studi Masyarakat, Religi, dan Tradisi), 1(1), 41-54. https://doi.org/https://doi.org/10.18784/smart.v1i1.228

Haryanto, J. T. (2018). Nilai Kerukunan pada Cerita Rakyat Dayuhan-Intingan di Kabupaten Tapin Kalimantan Selatan. Jurnal SMART (Studi Masyarakat, Religi, dan Tradisi), 4(1), 1-14. https://doi.org/https://doi.org/10.18784/ smart.v4i 1.598

Ishar, A. (2015). Sejarah Kesultanan Melayu di Kalimantan Barat. Pontianak: STAIN Pontianak Press.

el Harakah Jurnal Budaya Islam Vol. 23 No. 1 Tahun 2021 
Jamalie, Z. (2014). Akulturasi dan Kearifan Lokal dalam Tradisi Baayun Maulid pada Masyarakat Banjar. El Harakah, 16(2), 234-254.

Jones, S. (2013). Sisi Gelap Reformasi di Indonesia: Munculnya Kelompok Masyarakat Madani Intoleran. Paper presented on Nurcholish Madjid Memorial Lecture (NMML). Jakarta.

Klinken, G. V. (2007). Communal violence and democratization in Indonesia: Small town wars. https://doi.org/10.4324/9780203965115

Kristianus (2016). Politik dan Strategi Budaya Etnik dalam Pilkada Serentak di Kalimantan Barat. Politik Indonesia: Indonesian Political Science Review, 1(1), 87. https://doi.org/10.15294/jpi.v1i1.9182

Labov, W. (1978). Language in the inner city: Studies in the Black English vernacular. Philadelphia: University of Pennsylvania Press.

Magenda, B. D. (2014). Dinamika Peranan Politik Keturunan Arab di Tingkat Lokal. Antropologi Indonesia, 29(2), 182-197. https://doi.org/10.7454/ ai.v29i2.3535

Markhamah (2000). Bahasa Jawa keturunan Cina di Kota Madya Surakarta. Universitas Gadjah Mada.

Prasojo, Z. H. (2011). Indigenous Community Identity within Muslim Societies in Indonesia: A Study of Katab Kebahan Dayak in West Borneo. Journal of Islamic Studies, 22(1), 50-65. https://doi.org/https://doi.org/10.1093/ jis/etq068

Purba, J. (2014). Sejarah dan Perkembangan Kebudayaan Melayu di Kalimanatan. Pontianak: STAIN Pontianak Press.

Riyanto, S., Surwandono, S., Warsito, T., \& Cipto, B. (2018). Islam dalam Politik Luar Negeri Singapura. Jurnal Hubungan Internasional, 7(2), 205-216. https://doi.org/10.18196/hi.72138

Ruslan, Ismail \& Hasriyanti, N. (2019). Kajian Sosiologis tentang Eksistensi Perempuan di Tepi Sungai Kapuas, Pontianak - Kalimantan Barat. Raheema, 5(2), 127-138. 
Salim, H. (2012). Strategi Penanggulangan Konflik Keagamaan di Kalimantan Barat dalam Mengukuhkan Kerukunan Umat Beragama di Kalimantan Barat. Pontianak: FKUB Kalimantan Barat.

Suminto, R. M. \&, \& Ermawati, P. (2018). Potret Perempuan Dayak Iban, Kayan, Desa, dan Sungkung di Kalimantan Barat. Specta: Journal of Photography, Arts, and Media, 1(1), 51-66. https://doi.org/10.24821/ specta.v1i1.1897

Sutantri, S. C. (2018). Diplomasi Kebudayaan Indonesia dalam Proses Pengusulan Pencak Silat Sebagai Warisan Budaya Takbenda Unesco. Jurnal Ilmu Politik dan Komunikasi, 08(1). https://doi.org/10.34010/JIPSI.V8I1.876

Veth, P. (1854). Borneo's Wester Afdeeling, Geographisch, statistisch, historisch. Zaltbommel: Joh Noman en Zoon.

Widjaya, A. (2013). Sejarah, Konsepsi dan Cita-cita Perjuangan Gerakan Pemberdayaan Pacur Kasih (GPPK). In Francis X Wahono (Ed.), Gerakan Pemberdayaan Pancur Kasih. Pontianak: Institut Dayakologi.

Widjono, R. H. (1998). Dayak Menatap Hari Esok. Jakarta: Gramedia Widiasarana Indonesia.

Yusriadi \& Muttaqin, I. (2018). Heterogeneous Islam as a Cultural Identity of Multicultural Communities in the Suburbs of Pontianak. Al-Albab, 7(1), 115-130. https://doi.org/10.24260/alalbab.v7i1.1094

Yusriadi; Ruslan, I. \&, \& Hariansyah. (2018). Narasi Kebahan sebagai Resolusi Konflik pada Masyarakat Nanga Pinoh, Melawi. Jurnal SMART (Studi Masyarakat, Religi, dan Tradisi), 4(1), 15-26. https://doi.org/10.18784/ smart.v4i1.583

Yusriadi (2008). Memahami Kesukubangsaan di Kalimantan Barat. Pontianak: STAIN Pontianak Press.

Yusriadi (2014). Bahasa dan Identiti Melayu di Riam Panjang. Bangi: ATMA.

Yusriadi (2018). Identity of Dayak and Melayu di Kalimantan Barat, 1(2), 1-16. https://www.researchgate.net/publication/331237584_Identitas_Dayak_ Dan_Melayu_Di_Kalimantan_Barat/link/5c6e017c299bf1e3a5b8d011/ download

el Harakah Jurnal Budaya Islam Vol. 23 No. 1 Tahun 2021 
